\title{
Drivers of violent conflict
}

\author{
Maria Kett ${ }^{1} \quad$ Michael Rowson ${ }^{2}$
}

$J$ R Soc Med 2007; 100:403-406

\section{BACKGROUND}

In March 2007, the UK Department for International Development (DfID) launched a policy paper on 'Preventing Violent Conflict'. ${ }^{1}$ At the launch, held in the Cabinet War Rooms, the then Secretary of State for International Development, Hilary Benn, outlined the links between the prevention of violent conflict and the alleviation of poverty, international security and protection of basic human rights for all.

The impact of violent conflict on health is evident. In countries affected by conflict, health systems are destroyed and take years to regenerate. The effects of the conflict and ensuing poverty are demonstrable across indicators such as maternal and child mortality rates, nutrition and infectious diseases. Displaced populations suffer high rates of mortality, particularly in the early stages of displacement; communicable diseases and psychological distress are commonplace, as are injuries from antipersonnel mines, firearms and other violent acts. Understanding the causes of violent conflict and working towards prevention is an important part of promoting health at a global level.

\section{DRIVERS OF CONFLICT: GREED OR GRIEVANCE?}

There has been a major shift in the nature of modern conflict, from traditional symmetrical conflicts (e.g. between armies), to increasing numbers of intra-state conflicts and asymmetric wars (e.g. between state and militia). Armed conflicts in the Horn of Africa have had a huge impact on development priorities in the region, yet they are not measured as formal armed conflicts. ${ }^{1}$ Some argue that there are no legitimate causes for such wars. This effectively criminalizes them, as it does not explore the factors that cause, trigger and sustain conflicts-put differently, the factors that drive conflict.

Whilst the term 'drivers' implies the dynamic nature of the factors and processes that contribute to violent conflict, there is a great deal of debate about reducing wars to one

\footnotetext{
${ }^{1}$ Leonard Cheshire Centre of Conflict Recovery, University College London, 4 Taviton Street, London WC1H OBT, UK

Email: m.kett@ucl.ac.uk

${ }^{2}$ Centre for International Health and Development, Institute of Child Health, University College London, UK

Email: mrowson@ich.ucl.ac.uk
}

'cause': for example, saying that the war in Sierra Leone was about diamonds is of course a gross oversimplification.

Political and economic relationships between and within states clearly matter if we want to tackle violent conflict. Yet when it comes to identifying the drivers of conflict in particular situations, fierce debates break out. Take the case of the US-led invasion of Iraq in 2003. Some argued that economic interests - the control of oil supplies - lay behind the invasion. Others took a different view - that the invasion was driven by a political imperative to bring democracy to a country (and a region) whose autocratic nature had become a threat to international security.

A similar polarization has afflicted academic debate on the root causes of war, to the extent that some cannot even bear to use the phrase 'root causes', as they see it as inextricably linked with the idea that there is some justifiable grievance behind every outbreak of conflict. $^{2}$ Whilst some have traditionally focused on these grievancerelated drivers of conflict, such as poverty and inequality, another strand of thinking has suggested that the incidence of war is dependent on material interests instead. In other words it is greed rather than grievance which creates armed conflict.

Polarized views on either side have been bolstered by a rash of dubious statistical attempts to isolate specific underlying causes. Yet as we have argued, it is difficult to define war or armed conflict, let alone gather solid data on its possible causes. Nevertheless, this does not make it any the less important to understand why violent conflict occurs; in fact, the extent of the health implications of war make it vital that we look at its precursors. Inevitably many factors are linked, such as climate change and political processes, but here we concentrate on the economic debates.

\section{DOES POVERTY CAUSE CONFLICT?}

Some of the world's poorest countries are riven by armed conflict, such as Liberia, Sierra Leone, Haiti and the Democratic Republic of Congo. Cross-country comparisons show that conflict-related humanitarian emergencies are prevalent in those places that have experienced low or negative economic growth. The grind of long-term poverty leads to dog-eat-dog behaviour, weakens the ability of the state and communities to redistribute wealth in the face of economic grievance and provokes the rich to grab the assets 
of the poor. ${ }^{3}$ On the positive side, there is evidence to show that economic growth can reduce the risk of conflict in lowincome countries. ${ }^{4}$ This fits with the classical view, elegantly put by Keynes, that economic development would 'turn interests against passions', 5 binding people together in denser sets of economic relationships and making it less likely that any group would spoil stable economic co-operation by resorting to violence.

Inevitably, violent conflict impacts on the ability of states to function effectively, and they become trapped in what seems like an endless cycle of poverty, conflict and under-development, each exacerbated by the other, which in turn increases vulnerability and impedes economic growth and development: Collier and Hoeffler ${ }^{6}$ have calculated that 'the cost of a civil war in a typical developing country is at least US $\$ 64.2$ billion, including the value of the lost output as well as the value of the lost life and health.' ${ }^{\prime}$

Yet conflict obviously does not just afflict the poorest countries, as 'the troubles' in Northern Ireland and the devastating civil wars in Algeria and former Yugoslavia during the 1990s show. Many poor countries are not at war; shared poverty may not be a destabilising influence. ${ }^{3}$ Indeed, economic growth itself can destabilize, as the wars in countries afflicted by an abundance of particular natural resources appear to show.

\section{NATURAL RESOURCES}

Countries that rely heavily for the majority of their economic output on the production of one or a small number of natural resources (such as oil, timber or diamonds) seem to be more prone to conflict. ${ }^{4}$ Governments that are in this situation need to manage their resources carefully. Too often, however, they distribute revenues from natural resource production unevenly, or even use them to wage war against their own population. The presence of natural resources encourages rebel groups to spring up to capture some of the pie. Paul Collier and colleagues have pointed out that diamond or timber production does not require complex technology and can be captured quickly by militias. ${ }^{4}$ Simple drug production also finances guerrillas the world over. In Sierra Leone, the Revolutionary United Front financed itself by taxing coffee producers before moving on to diamonds. ${ }^{4}$ Where multinational firms are needed to undertake more complex forms of production (for example of oil), rebels have even resorted to kidnapping their employees, as happens regularly in places such as Colombia and the Niger Delta. ${ }^{4}$

Examination of the role of natural resources in perpetuating several contemporary conflicts has led to a focus on how material interests can initiate and prolong conflict. Greed becomes the explanation for the outbreak of war. Yet it would be unwise to say that natural resources are predictive of conflict-indeed, $\mathrm{Cramer}^{8}$ notes one statistical study which says that there is no relationship between the incidence of war and presence of natural resources. James Fairhead ${ }^{9}$ has made a convincing argument that over-causation of the links between the environment and conflict can result in the depoliticization of conflict and ignores the economic basis of these conflicts: for example, to say that diamonds are the cause of conflict in Sierra Leone would ignore other factors such as high unemployment, particularly among the young.

\section{INEQUALITIES}

Turning to look at another source of grievance widely cited as triggering conflict, namely income inequality, here again cross-country statistical analysis produces divergent results. For example, Alessina and Perroti's 1996 study of 71 developing countries found that income inequality is related to instability, ${ }^{3}$ whereas others have found no such relationship. ${ }^{8}$ Given that inequality only changes slowly over time, while conflicts break out with great rapidity, can we expect that inequality is the prime mover in their causation ${ }^{5}$ Probably not-but that does not mean we should rule out a role for inequality.

Some evidence suggests that analysis should focus on where particular groups of people-whether they are clans, tribes, ethnic groups or classes - feel collectively deprived and at the sharp end of an unequal distribution of political and economic resources. Case study, rather than statistical analysis, suggests that these types of group-based (or 'horizontal') inequalities can be profoundly destabilizing. ${ }^{10}$

Stewart's research ${ }^{10}$ demonstrated that horizontal inequalities are most likely to escalate into conflict when they are substantial, consistent and increase over time. For example, in Sri Lanka after independence the Tamil population suffered a sharp reversal in their social, economic and political status as the majority Sinhala population came to power. Demands for a separate Tamil state grew and broke into armed rebellion in the $1980 \mathrm{~s} .{ }^{10} \mathrm{In}$ Nepal, too, deep differences between caste and ethnolinguistic groups have created horizontal inequalities and facilitated the emergence of the conflict between the government and Maoist insurgents. Brown and Stewart ${ }^{11}$ note that inequalities in human development and land ownership correlate well with the intensity of the Maoist insurgency at the district level. Only recently have these inequalities begun to be addressed in Nepal by the government and international aid donors.

So, is it greed or grievance that is the cause of violent conflict? Jonathan Goodhand ${ }^{12}$ has argued that it is both greed (opportunity for accumulation) and grievance (generated by poverty and social exclusion) that cause and 
perpetuate violent conflict. He also raises the important point that notions of social and human vulnerability are transient - and it is this very transience that can be a trigger factor for violent conflict. According to this line of argument, someone who has had access to wealth and who then loses it suddenly is more likely to be aggrieved than someone who never had such access in the first place. What this review and many others have shown is that researchers should resist looking for one particular explanation for the incidence of violent conflict: all wars are produced by multiple confluences of deep underlying causes and sudden triggering events. But are there some priorities for governments and aid donors to address amongst the list of underlying causes we have discussed?

\section{PREVENTION}

As the recent DfID policy paper Preventing Violent Conflict ${ }^{1}$ demonstrates, whatever the causes of violent conflict may be, there is now a commitment on behalf of governments, international observers and institutions to try and alleviate the sheer cost, human and otherwise, of violent conflict. The paper highlights three main areas where this can most effectively be done: greater emphasis on preventing violent conflicts erupting in the first place; improving the effectiveness of responses to violent conflict; and making all (DfID's) development work 'conflict sensitive'.

It is now widely acknowledged that preventing violent conflict erupting in the first place is the best option. Not only is it far more cost effective, but as noted above, it is evident that once conflict has erupted, it is highly likely to re-erupt unless certain conditions are met. These include acknowledging and alleviating horizontal inequalities and addressing grievances. The focus on poverty alleviation should not be just about increasing economic output, though of course this is vital, but also about ensuring sustainability and equity. Notable preventive factors include securing access to education and employment for young people.

Distribution of wealth from natural resources requires national and international action. At the international level there has been a shift toward more corporate social responsibility and international agreements on trading valuable resources, such as the Kimberly Agreement regarding trading of 'conflict' diamonds. At the national level, governments need to focus on redistributing the proceeds of economic growth to the benefit of the whole population: natural resources need not be a curse, as the diamond-financed Botswanan economy shows.

Donors are only just beginning to engage with this conflict prevention agenda. They have had more experience with post-conflict situations - a particularly sensitive time given that countries emerging from violent conflict are prone to relapse. Successful interventions include rehabilitation and reconstruction programmes, support for good governance and civil society organizations, military accountability and protection of human rights. Yet it is also the case that international humanitarian aid has sometimes inadvertently contributed to the continuation of conflicts, for example through funding and legitimizing warlords. ${ }^{13}$

Indeed, without a 'conflict sensitive' approach to development programming, interventions may inadvertently exacerbate or reinforce conflicts by increasing competition for resources, introducing new institutions that challenge existing ones, or by helping to perpetuate structures of dominance. Assessment tools are constantly being developed to assist our understanding about the processes by which post-conflict transformations happen, and the strategies that have the most successful political, social and economic impacts. This is an approach that donors and humanitarian agencies are increasingly undertaking as recovery from conflict and complex emergencies is recognized as a dynamic process that can be enhanced or exacerbated through the incorporation of peace building tools into programmes ${ }^{14}$

\section{CONCLUSION}

This paper has highlighted some political and economic relationships between and within states that contribute to violent conflict. Understanding the drivers for conflict is far from complete; however, both material interests and legitimate grievances play a role in increasing the risk of violent conflict. It is also important to recognize that many factors can lead to and perpetuate violent conflict. The costs to health and well-being are so great that working on ways to reduce violent conflict remains a vital task.

Competing interests The authors are involved in a European Union-funded project creating interactive learning materials on health, violent conflict and peace. See http://www.medicalpeacework.org

\section{REFERENCES}

1 UK Department for International Development. Preventing Violent Conflict. London: DfID, 2006

2 Collier P. Ethnic civil wars: securing the post-conflict peace. Harvard International Review 2007;28:56-60

3 Nafziger EW, Auvinen J. Economic Development, Inequality and War: Humanitarian Emergencies in Developing Countries. Basingstoke, UK: Palgrave Macmillan, 2003

4 Collier P, Elliott VL, Hegre H, Hoeffler A, Reynal-Querol M, Sambanis N. Breaking the Conflict Trap: Civil War and Development Policy. Washington DC: World Bank and Oxford University Press, 2003

5 Cramer C. Inequality and Conflict: A Review of an Age-Old Concern. Identities, Conflict and Cohesion Programme Paper Number 11. Geneva, United Nations Research Institute for Social Development, 
2005. Available at http://www.unrisd.org/unrisd/website/ document.nsf/d2a23ad2d50cb2a280256eb300385855/0501d4f6b3083 076c12570b4004f0d5b/\$FILE/cramer.pdf

6 Collier P, Hoeffler A. Greed and grievance in civil war. Oxford Economic Papers 2004;56:563-95

7 Addison, T. Post-Conflict Recovery: Does the Global Economy Work for Peace? Helsinki: United Nations University/World Institute for Development Economics Research, Discussion Paper No. 2005/05

8 Cramer C. Does inequality cause conflict? J Int Dev 2003;15:397-412

9 Fairhead J. Conflict over natural and environment resources. In: Nafziger EW, Stewart F, Väyrynen R (eds). War, Hunger, and Displacement: The Origins of Humanitarian Emergencies. Oxford: Oxford University Press, 2000

10 Stewart F. Horizontal Inequalities: A Neglected Dimension of Development. Helsinki: United Nations University/World Institute for Development
Economics Research, 2001. Available at http://www.wider.unu.edu/ publications/annual-lectures/annual-lecture-2001.pdf

11 Brown G, Stuart F. The implications of horizontal inequality for aid. CRISE working paper 36. Oxford: Centre for Research on Inequality, Human Security and Ethnicity, 2006. Available at http:// www.crise.ox.ac.uk/pubs/workingpaper36.pdf

12 Goodhand J. Enduring Disorder and persistent poverty: a review of the linkages between war and chronic poverty. World Dev 2003;31: $629-46$

13 Anderson M. Do No Harm: How Aid Can Support Peace, or War. Boulder, CO: Lynne Rienner, 1999

14 Conflict Prevention and Post Conflict Reconstruction Network. Peace and Conflict Impact Assessment (PCIA) Handbook. Utrecht: CPR Network, 2005. Available at http://www.humanrightsimpact.org/publications/ item/pub/175/ (accessed 17/07/2007)

\title{
Electronic Monthly Updates from the RSM Library
}

\author{
Too many journals? Not enough time? You need an EMU! \\ By setting up an EMU with us, up-to-date key information is \\ automatically delivered direct to your desktop... FAST!
}

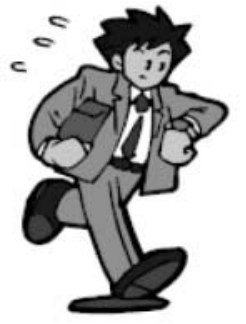

EMUs are easy to set up:

$\checkmark$ Define your specific information criteria

$\checkmark$ Choose your database

$\checkmark$ Supply us with your e-mail address

$\checkmark$ We'll do the rest!

Available to RSM Members only. For further information, please contact Beata Kloska, Information Specialist (Search Services), RSM Library

Tel: 02072902937

E-mail: EMU@rsm.ac.uk

Web: http://www.rsm.ac.uk/librar/emu

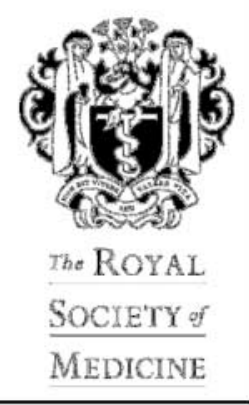

